\title{
Analysis of Sources for Information Gathering before Visiting a Festival in the Case of Generation Z
}

\author{
Tamás Iványi $i^{1 *}$ \\ 1 Department of Management and Business Economics, Faculty of Economic and Social Sciences, Budapest University of

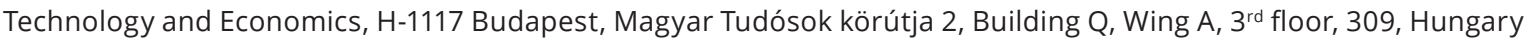 \\ *Corresponding author, e-mail: ivanyi.tamas@gtk.bme.hu
}

Received: 15 March 2020, Accepted: 26 July 2020, Published online: 16 July 2021

\begin{abstract}
In recent years, festivals have become an essential part of summer activities for many members of Generation Z. Programs that last several days also mean significant financial burden for young people, so they gather information from multiple sources before decision-making. The purpose of the study is to examine which information sources - especially social media - and which motivations have become significant in the context of festival tourism's decision process.

An online survey was conducted as part of and exploratory research over four consecutive years dealing with the use of information sources and the importance of the music festivals' characteristics targeting the Hungarian Generation Z attendees of festivals. Besides the descriptive statistics cluster analysis and ANOVA tables were used.

It can be emphasized that in the case of festival tourism, the influence and usage of social media, relying on the opinions of acquaintances and friends is much more significant in the decision-making phase than in the case of traditional tourism. The program and the leading performers are not the only important factors, but meeting friends, the atmosphere of the festival, and reasonable value for money are also significant. Three groups of users could be identified: those who are mainly browsing official websites and search engines, those who try to make decisions based on earlier experiences, and those who are also looking at social media sites and digest several types of content to make the decision. Organisers of festivals should understand the differences among these groups to create better communication strategies.
\end{abstract}

\section{Keywords}

consumer decision process, generation Z, festival tourism, tourism marketing

\section{Introduction}

The importance of the Internet has grown significantly during the last decade in the field of tourism (Confente and Vigolo, 2018; Navío-Marco et al., 2018). During the last few years, the Internet also became a valuable information source not just in the pre-trip planning phase but also during the trip and for sharing information after the trip (Kang et al., 2019). Using social media platforms also became a significant source for information gathering, and smartphones as devices to browse the Internet can influence the travel decisions of many people (Wang et al., 2016; Xiang and Gretzel, 2010). Both younger and older generations use different types of websites and their smartphone to find information before and during traveling. Literature also suggests that different generations use online platforms in different ways and also have different behaviour in tourism (Kim et al., 2015; Yoo and Gretzel, 2009).
The number of festivals aiming at tourists and also locals has been increasing during the last few years, and these have become an essential factor in tourism (Ásványi et al., 2019; Hinek and Kulcsár, 2019). These tourist attractions can offer an extraordinary experience not only for tourists but locals also (Pomucz and Csete, 2015). Local festivals and the most important Hungarian music festivals are also frequent destinations for the members of Generation Z (Kántor, 2019; Székely and Szabó, 2017). These are not just frequently visited festivals, but youngsters also say that among others, music and gastronomy festivals are famous tourist attractions of Hungary (Süli et al., 2019).

In this research paper, the focus is on festival tourism and Generation $\mathrm{Z}$, the most important visitors of music festivals (Vági, 2009). We deal with the first phase of 
tourism, the pre-trip phase (Choe et al., 2017), when potential travelers gather information and make decisions.

To understand this phase of Generation Z's festival tourism three research questions were formed:

1. Is there a difference between regular tourism (like city breaks) and festival tourism in respect of information gathering from social media? Which are the most important platforms and sources?

2. What are the most critical decision factors for the visitors of a festival?

3. Can we form groups of visitors based on the information gathering preferences?

Besides the literature review, the results of a quantitative survey are also presented. The survey was conducted for four consecutive years (from 2016 to 2019).

\section{Literature review}

\subsection{Information gathering of younger generations in tourism}

In this research paper, we focus on the needs of Generation Z, also called the N-generation (net generation), which generation was defined among others by Prensky (2001). Generation Z, consisting of those who were born between 1995 and 2010, is a more online than offline generation. This generation is characterised by the fact that they started to use the Internet and computers during the era of Web 2.0 (Pál, 2013).

Töröcsik (2011) points out that the communication attitudes and media repertoire of different generations differ significantly. For younger people, social media and online two-way communication are much more important than for older people. Members of this generation are seeking and using applications that, besides providing information, also supports the creation of information (Hack-Handa and Pintér, 2015). Thus, the members can have a constant two-way communication connection between each other (Nagy and Fazekas, 2016). Hardey (2011) proposes a nonage-related, but rather behaviour-related generation classification using the letter $\mathrm{C}$, that stands mainly for content creation, but is supported by additional C's like creativity, casual collapse, control and celebrity. Being a member of Generation $\mathrm{C}$ can also mean being a member of Generation $\mathrm{Z}$ too, as literature suggests that Generation $\mathrm{Z}$ also engages in several content creating activities (Töröcsik et al., 2014). According to the Eurobarometer 2015 survey about the most popular online activities, $86 \%$ of the group of 15-24 aged youngsters like to use the community based social networking sites that offer content creation. This is a much higher proportion than the general $60 \%$ percent concerning the same activity for the "older than 15 years" group in the survey (Nagy and Fazekas, 2016). Töröcsik et al. (2014) emphasize that the members of Generation $\mathrm{Z}$ together form a global generation, according to which the tools, platforms, devices they use, such as communication solutions, are the same regardless of the countries they are from.

It is hard to show overall results of the usage of information channels for travelling purposes. According to Choi et al. (2012) it can depend on the destination, the purpose, the timing of the trip and the travel product too. They investigated that travellers use different types of sources before and after the decision about the destination. In addition, significant differences could be shown in respect of different lengths of stay, numbers of companions and visiting experiences. Kim et al. (2015) show that although the Internet is an essential source for all generations that they examined (from silent generation - born before 1945, to generation Y - born between 1981 and 1995), there are significant differences among the generations based on which type of websites they search for and which online activities they do. They also show that previous travel experience is less important for the younger ones. Personal blogs, consumer-generated content, photo or video sharing sites and social network sites are much more important for younger generations in tourism decision making than for the older ones. From social media sites, only the special interest and online community sites (like TripAdvisor) have more or less the same importance for all generations. Xiang et al. (2015) show that from 2007 till 2012 the most significant increase was detected in the case of reading other travellers' comments and posts $(13.4 \%)$ and watching videos (15\%). Also, a relevant increase was observed in the case of using social network sites $(13 \%)$ and photo and video sharing sites (8\%).

Nemec Rudež and Vodeb (2015) tried to understand Croatian students' information search on social media for a trip. They found that before the trip, social media usage has two goals: searching for opinions and gathering information for comparison. During the trip, sociability appears besides searching for information; after the trip, sociability is the only important factor. Zavodna and Zavodny Pospisil (2018) conducted the same survey for Czech students and found that more than half of the students use social media, mainly for getting others' opinions. According to them, the most important social media platforms are Facebook (82\%), Instagram (54\%) and YouTube (35\%). 
Süli and Martyin-Csamangó (2017) for Hungarian youngsters found that Facebook, Instagram, Google and Snapchat were the most important platforms in the case of two local music festivals. They also found that Facebook, Instagram and Snapchat were the most frequently used platforms to share their experiences at the festivals. Kim et al.'s (2015) statistics also showed that reading blogs, using live chat and watching videos are relevant activities for the younger ones.

To understand the importance of social media and tourism, Kang and Schuett (2013) say these are both socially constructed, and sharing is a keyword for both. Huang et al. (2017) found the use of smart tourism platforms (like social media sites) both in case of exploration and exploitation can enhance the travel experience and overall transaction satisfaction. The motivation for using a social media channel can be, for example, a felt need for social interactions, community development and self-expression too (Munar and Jacobsen, 2014). The use of a smartphone today has become the tool for finding outstanding experiences and for achieving self-actualisation and self-expression (Lai and Katz, 2012), and these aims can be realised through social media platforms.

Choe et al. (2017) discuss that users of the Internet create their own media repertoire and use it in different patterns during the pre-, on- and post-trip phases. They focus on social media which is categorized into travel reviews (like TripAdvisor), social networking (like Facebook), photo and video sharing (like Instagram feed, YouTube), microblogs (like Twitter or Instagram Story, Snapchat), personal blogs and special interest communities (forums and bulletin boards). They also investigated the change of behaviour from pre-trip to on-trip and from the on-trip to post-trip phase. The majority of the active social media users in pre-trip became non-users and a few of them became socialisers during the trip. After the trip, the majority of non-users remained non-users, but some of them became socialisers too.

Evans (2008) connects the so-called post-purchase phase (which can be interpreted as the on-trip and posttrip phase in the case of tourism) to the information gathering and decision-making part of the customer journey through social media. He says that users (visitors in this case) form an opinion and talk about them. This social media feedback cycle has important effects on another customers' consideration. Lecinski (2011) created the model called Zero moment of truth, which emphasizes the same feedback cycle. He shows that after the stimulus, consumers immediately start to gather information mainly through their smart devices and using social media platforms. This also shows the increasing importance of the opinions of other consumers. This means that socialisers, and transforming people into socialisers during the post-trip phase (Choe et al., 2017) can be a relevant target for the organisers. Semrad and Rivera (2018) - focusing on festivals in their research - found that creating a better overall festival experience - based on several experience factors together - has a significant effect on the users' post-trip behaviour, like sharing experiences, starting the electronic Word-of-Mouth.

Confente and Vigolo (2018) created two models to understand the most critical factors in online booking before traveling. Although the experience of previous online purchases is vital for everyone, there are significant differences among the cohorts for online word-ofmouth that can be spread through social media: despite being essential for each generation, the standardised beta value in hierarchical regression was significantly different. The highest value was for Generation Y and lowest for the Silent Generation.

Kang et al. (2019) showed differences in the characteristics of consumers between those who used smartphones and who did not use smartphones (although they had one) for travel-related information search before a trip. Significant differences were discovered in age, income, employment and education too. Kang et al. (2019) also dealt with the differences in information types that are searched for before and during a trip. Since smartphones are important devices for on-trip information gathering, their statistics relating to during-the-trip information categories are relevant. More than one-third of the sample said that they search for activities, restaurants, attractions and destinations before and during the trip too.

\subsection{The importance of music festivals in Hungary}

The aim of events is enchasing the mood of the people, providing experience and letting them escape from their everyday life (Harsányi, 2013:pp.300-301). To define touristic events, the most important factors are that these are pre-organised, temporarily available, have a purpose as such, and a specific aim and place (Fazekas and Harsányi, 2011). Getz (2008) and Morgan (2008) meanwhile provide several, quite similar definitions of events in tourism. The most important factors are: these events emerge with a good idea, they have a cultural basis, and events are carefully designed experiences where people get together, and these have a particular duration and concept. 
Festival tourism is an increasingly popular feature of event tourism. Festival tourism happens when people travel to a destination at the time of the festival to visit at least some of the events (O'Sullivan and Jackson, 2002). There are different types of festivals, but in many cases, a festival can belong to several categories and can include numerous types of cultural-artistic events (Hunyadi et al., 2006). According to the Hungarian Festival Organization festivals have cultural, artistic, gastronomic, sports or other themes, and these have educational, entertaining or recreational purposes, providing also a community experience (Ásványi et al., 2019). Jászberényi et al. (2016) describe the festivals as usually a secondary attraction of the destination because they can enhance the consumer's perceived value, but usually the visitors choose a destination not because of the festival itself. Nevertheless, a festival - especially music festivals - for younger generations can also function as a primary attraction. This type of event encourages tourists to consume more and more, stay longer at the destination, meaning the events "strengthen the attractiveness of tourist destinations" (Husz, 2012:p.94).

In Hungary, the most important and most popular music festivals are Sziget Festival, VOLT, Balaton Sound, EFOTT and Strand. These names have also become trademarks of Hungarian festival tourism (Magyar Turisztikai Ügynökség, 2017). Süli et al. (2019) asked Hungarian members of Generation $\mathrm{Z}$ about the most important touristic features of Hungary: music and gastronomy festivals were frequently mentioned. There are several literature sources which have analyzed the habits of Hungarian youngsters about their music festival attendance and can be used to define the target population of a questionnaire about music festivals in Hungary (Deli-Gray, 2010; Kovács, 2009a; 2009b; Rátz, 2012; Sija and Schauermann, 2009). The target population for the quantitative research in this paper was also based on these resources.

Rátz (2012:p.38) outlines the results of a survey that observes the experience elements as motivating factors for choosing Sziget Festival in the consumer decision-making process. According to the results, concerts and music received the highest score on a 5-point scale (4.51), it is closely followed by being with friends (4.47). Partying at the festival can also be an important factor (4.26), and curiosity (3.99) and cultural programs (3.19) also appeared for several visitors. In 2010, the least motivating factor was getting to know new people, acquiring new friends (2.86) and the influence of family members and friends (2.62). Similar to these results, Sija and Schauermann (2009) show that participating in a party is the most essential factor for music festival visitors $(83.6 \%)$, the second one is the specific artists playing at the festival (54.2\%). Getting to know new people (35.1\%), further cultural programmes $(28.4 \%)$ and friends also being there $(25.1 \%)$ are also significant motivating factors for choosing a music festival.

According to Sija and Schauermanns's (2009) survey of 15-25-year-olds: $56 \%$ had already attended a festival during the summer. $22 \%$ of young people attend festivals regularly, which means that they go to an event every summer. It can be summarized that $1 / 3$ of the Hungarian audience of Sziget Festival was under 20 years old, 3 out of 10 visitors were 20-24 years old, and less than $20 \%$ of the visitors are aged 29 and over. In the case of foreigners, the proportion of people over 29 is even lower (15\%), although visitors less than 20 years old alsorepresent under $20 \%$ of the overall audience (Kovács, 2009b). $60 \%$ of Hungarian visitors come from the capital and another $13.4 \%$ from Pest County. $55.6 \%$ of the visitors are full-time students; every second visitor attends university or college (Kovács, 2009b).

\section{Methodology}

Based on the results of previous researches by the authors, a questionnaire survey had been designed in 2016 and redesigned in 2019 to collect information about the factors of experience for Generation $\mathrm{Z}$ regarding tourism generally, festival tourism in particular and finally, specific festivals in Hungary. Information about different topics concerning tourism and festival tourism was included during the period of these years. Based on the literature review, several different questions were created to measure the importance of information sources and motivation factors:

1. In one multiple choice question, the visitors of the festivals had to indicate which channels (especially social media platforms) they used for information gathering and the decision-making process. This question type was asked for classical tourism and festival tourism too. It was included in the survey in every year without any change.

2. With semantic scale questions, the visitors had to show the importance too of the channels that they selected in the previous questions. The subquestions were filtered here based on the answers for question type $a$.

3. Using semantic scale questions, visitors had to show the importance of different factors and features of the festivals in the decision process. It was also included in the survey without any change during the period of years. 
The questionnaire was conducted four times: in the autumn of 2016, 2017, 2018 and 2019 (question type $b$ only in 2019). The target population was the members of Generation Z (only over 18 years and under 25 years) who live in Hungary and attended at least one music festival in the same year that the survey was conducted (used as a filtering question for festivals, but not for questions about tourism in general). Defining the target population this way made it possible to collect relevant answers concerning festival experiences each year and also allowed investigation of some trends and tendencies discernible during the years (Kim et al., 2015). A snowball sampling method was used to collect answers. Sampling was based on a homogeneous group, where members of Generation $\mathrm{Z}$ - mainly university students from Budapest and major Hungarian cities - were asked to participate through online mailing lists of universities and Facebook Groups.

During the sampling period in 2016 738, in 2017 572, in 2018 844, and in 2019572 valuable answers were received and analysed. For defining valuable answers, those who did not attended a festival in the same year were filtered out. The online survey system also saved data about the timing of when the questions were answered; this information was also used for filtering out unreliable answers. The demographic data of the filtered samples can be seen in Table 1.

The statistical evaluation was made with IBM SPSS v26 based on Sajtos and Mitev (2007). Besides descriptive statistics, ANOVA tables were used for comparing means and hierarchical cluster analysis was also conducted.

Table 1 The demographic data of the four sampling period

\begin{tabular}{|c|c|c|c|c|}
\hline Year: & 2016 & 2017 & 2018 & 2019 \\
\hline \multicolumn{5}{|c|}{ Sex } \\
\hline Male & $45.6 \%$ & $50.9 \%$ & $68.7 \%$ & $54.3 \%$ \\
\hline Female & $54.4 \%$ & $49.1 \%$ & $31.3 \%$ & $45.7 \%$ \\
\hline \multicolumn{5}{|c|}{ Age } \\
\hline 18 & $17.4 \%$ & $11.0 \%$ & $7.5 \%$ & $12.6 \%$ \\
\hline 19 & $36.8 \%$ & $33.6 \%$ & $21.0 \%$ & $28.6 \%$ \\
\hline 20 & $24.0 \%$ & $35.0 \%$ & $30.0 \%$ & $24.1 \%$ \\
\hline 21 & $10.0 \%$ & $8.9 \%$ & $24.8 \%$ & $18.6 \%$ \\
\hline 22 & $6.1 \%$ & $6.8 \%$ & $10.8 \%$ & $8.5 \%$ \\
\hline 23 & $3.0 \%$ & $2.8 \%$ & $3.5 \%$ & $3.3 \%$ \\
\hline 24 & $1.8 \%$ & $1.4 \%$ & $1.3 \%$ & $2.5 \%$ \\
\hline 25 & $1.0 \%$ & $0.5 \%$ & $1.1 \%$ & $1.8 \%$ \\
\hline \multicolumn{5}{|c|}{ Residency } \\
\hline $\begin{array}{l}\text { Capital } \\
\text { city }\end{array}$ & $48.3 \%$ & $47.7 \%$ & $43.5 \%$ & $48.2 \%$ \\
\hline City & $16.2 \%$ & $12.9 \%$ & $14.6 \%$ & $15.8 \%$ \\
\hline Town & $26.5 \%$ & $28.1 \%$ & $28.6 \%$ & $24.4 \%$ \\
\hline Village & $9.0 \%$ & $10.5 \%$ & $13.3 \%$ & $11.6 \%$ \\
\hline
\end{tabular}

For creating the clusters, the answers from question type $b$ were recoded into dummy variables (Sajtos and Mitev, 2007:p.293). Two dummy variables were created for each information source type in the questionnaire. These two variables can have four different states: not used by the user, less important ( 1 or 2 from the semantic scale of importance), mildly important ( 3 to 5 from the semantic scale) and very important (6 or 7 from the semantic scale).

Two-step clustering was conducted using hierarchical clustering methods: the first step was performed for filtering the outliers, and the second step used Ward's method to create the final clusters. By using this method, two to four clusters were created and analysed with ANOVA tables. Based on the scree diagram and the agglomeration schedule, it was decided to make use of three clusters (Hair et al., 2014; Sajtos and Mitev, 2007).

\section{Results}

Fig. 1 shows the tendencies of usage of different online platforms during information gathering in the case of music festivals. Although earlier studies (such as Kim et al., 2015; Xiang et al., 2015) showed the increasing importance of social networks from 2007 until 2012, based on the samples of the last few years, it seems that their importance is decreasing. Social networking sites mean mainly Facebook in Hungary and based on the general statistics of usage, members of Generation $\mathrm{Z}$ are rather using other types of social media applications (Lévai, 2018). This can explain the decreasing popularity of social network sites for Generation Z. Although video sharing sites (as part of the social media) are also quite popular, these have a slight decrease in frequency of usage too. Based on the results of the last four years in the case of photo sharing sites significant differences can be found, but tendencies can not be presented as it is fluctuating. These statistics are based on the whole sample; further is, however, possible for different segments as cluster analysis was also conducted.

In addition, it can be noticed that earlier experiences of the visitor are almost as meaningful as the experiences of friends and acquaintances. The frequency of both sources changed only slightly during these years. Official webpages are quite frequently used in every year and online search engines also had an increase in information gathering. This also means that the development and analysis of these websites (for example, in the case of search engine optimisation, as we can see online search engines are also frequently used) are essential questions (Bóta, 2009) for festival organizers. The increasing and decreasing usage of the other sources are also important information for the organisers. 


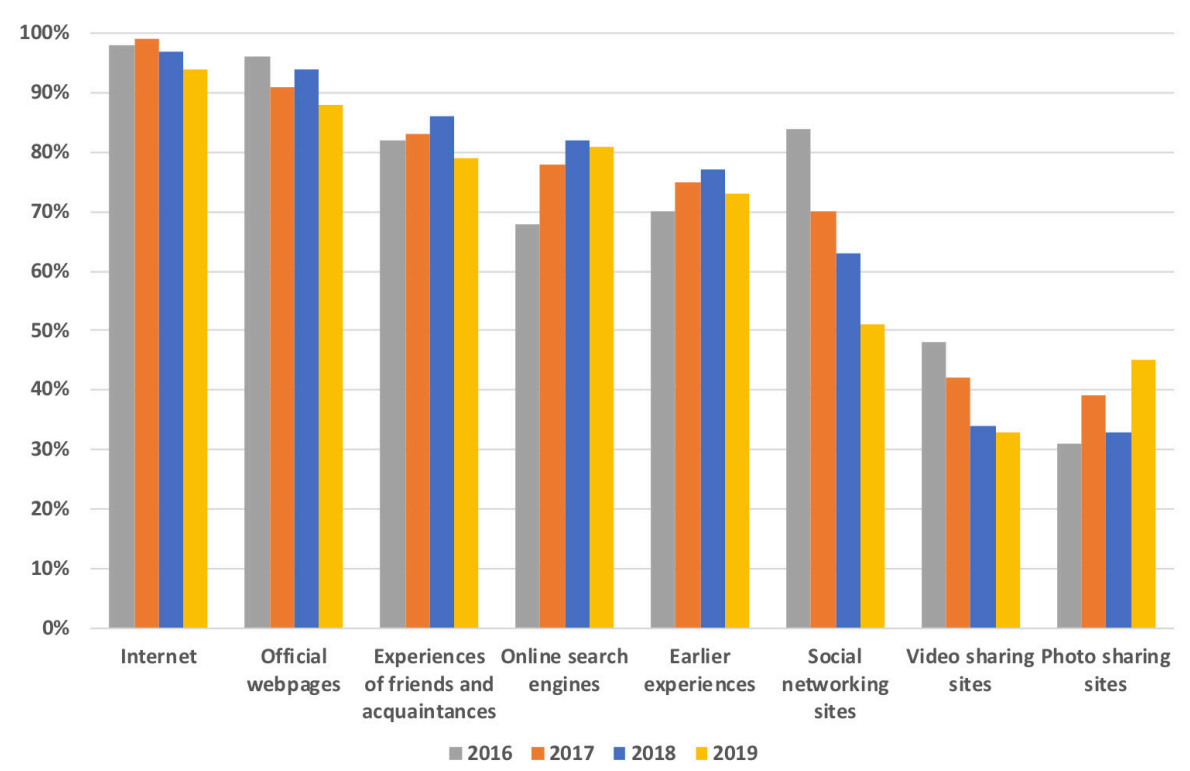

Fig. 1 The trends of the most important sources and platform for information gathering in the case of music festivals (2016 to 2019)

Differences between conventional travelling and visiting a festival were investigated, since the same multiple-choice questions (type a) were asked about classical trip planning (like city breaks, summer holidays) too. Fig. 2 shows the frequency of usage of the different platforms and sources in connection with both conventional travelling and visiting a festival.

Using the official webpages of the destination or the festival are both among the most frequently used sources for information gathering. Online search engines are used less in the case of festivals. That can be because information about a music festival is much concentrated on the
Internet, and travellers do not have to collect information about several sights or places, for example. As in the literature review it was mentioned (Kim et al., 2015), earlier experiences are less significant for younger generations in tourism, but in the case of festivals, based on the sample, it looks like this factor has a higher relevance. Although it can be seen that social network sites' importance is decreasing (Fig. 1), it is still much higher for festival tourism than in the case of trip planning. Interactive, user-generated content-based sites like TripAdvisor are the category of virtual communities. Not so many virtual community sites are available in the case of festivals, music festivals;

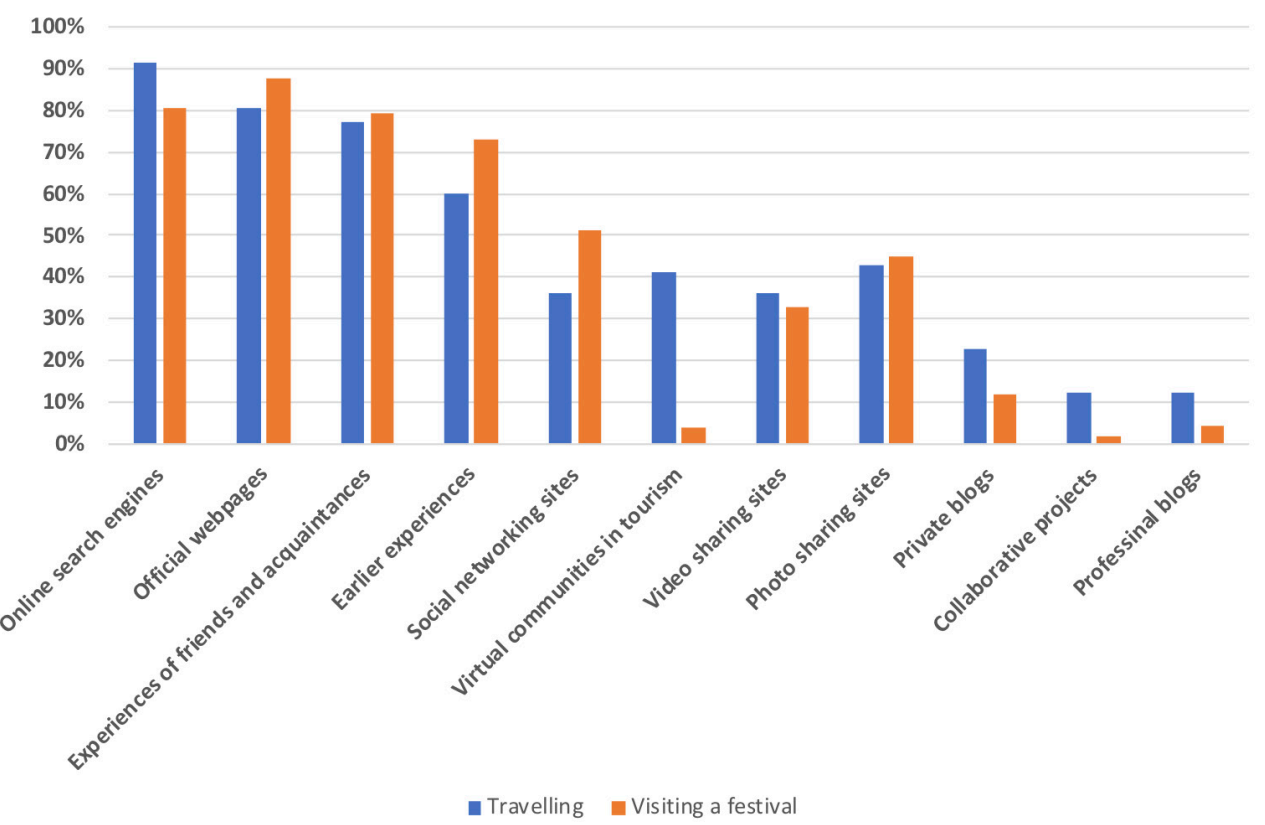

Fig. 2 Differences for travelling and choosing a music festival in the case of information gathering platforms (2019) 
these communities are mainly, for example, Facebook Groups functioning as bulletin boards. Creating websites for virtual festival communities could be a great opportunity for festival organisers, as these can collect data and feedback from festival visitors all over the world and can help users collect loads of information. These communities are created not just because it collects user-generated content but also to be a smarter alternative of general web searching pages. As search is less frequently used and less important (Fig. 3 and explanation later) in the case of music festivals, this function of virtual communities is not so required. However, some researchers suggest that feeling part of the community helps encourage tourists to share experiences (Drengner et al., 2012; Kazár, 2016), so these virtual community sites can help travellers to share experiences and provide the feedback loop suggested by Evans (2008) and Lecinski (2011). Also, collaborative projects like Wikipedia are not frequently used for information gathering in the case of a festival. Professional and private blogs (although there are a few of them dealing with musicians and music festivals) are not significant either for generation $\mathrm{Z}$ when they choose a music festival. Video and photo sharing sites are used with almost the same frequency in both cases.

Survey participants were also asked to rate the importance ofevery platform and source when the user marked them as a having been used during the information gathering process (question type b). Fig. 3 shows the results of the question about perceived importance in the case of the most frequently used information sources for decisions about festival tourism. As we can see, earlier experiences are really important for those who have them about previous festivals. Although social network sites are frequently used information sources, these are less important sources compared to photo sharing and mainly video sharing sites. Video sharing is less frequently used, but for those who use them, these are much more important than social network sites. There are many visitors who select a festival because of the atmosphere and the wish to attend good parties (Deli-Gray, 2010; Rátz, 2012). For these people, photos and especially videos can be significant sources that help them imagine the atmosphere and the parties of the festival. Also, we can see that experiences of friends and acquaintances are quite important in decision making. This result is consistent with Rátz's (2012), who shows that being with friends together is one of the most important reasons (besides the high value - price ratio and the performing musicians) to select a festival. This can be connected to the importance of friends' opinions during the decision process.

To understand the most important motivating factors that users base their festival decisions on, the importance of eleven factors were collected in the survey based on the earlier results shown in the literature review (Rátz, 2012; Sija and Schauermann, 2009). Fig. 4 shows the average values compared to each other in the same year as the relative importance of each factor. Based on the results of the last four years, the decision factors could be divided into three categories (see the blue rectangles in Fig. 4). Those that had more than $50 \%$ in relative importance every year are the high ratio of value and price, the atmosphere of the festival, specific artists and musicians, and being together with friends. As can be seen, the most important factor was the presence of friends each year. The atmosphere and the presence of friends can offer a guarantee of a good experience, so this can be an explanation as to why a lot of visitors of music festivals buy their ticket before the organizer announces the leading artists and the detailed programme.

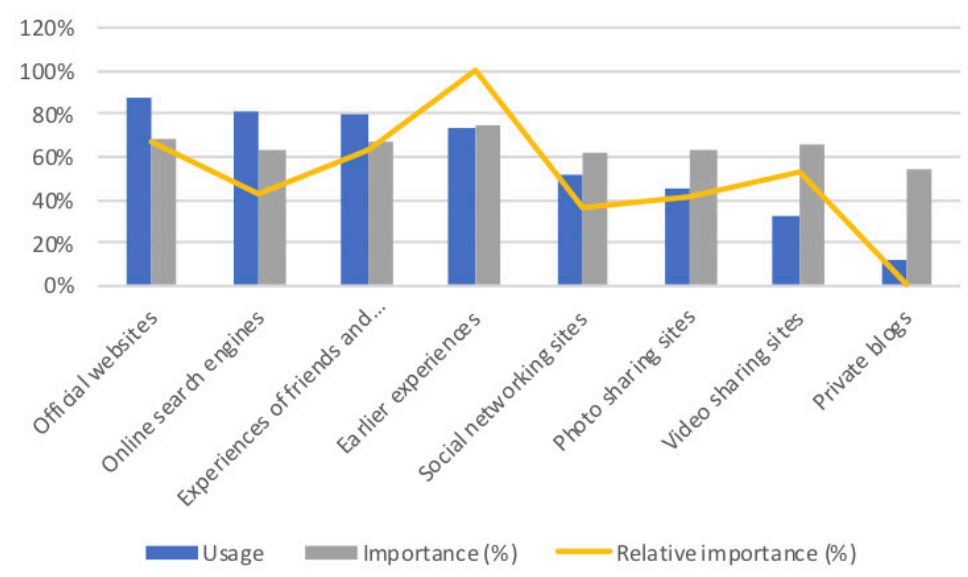

Fig. 3 Differences between importance, relative importance and frequency of usage in the case of music festivals 


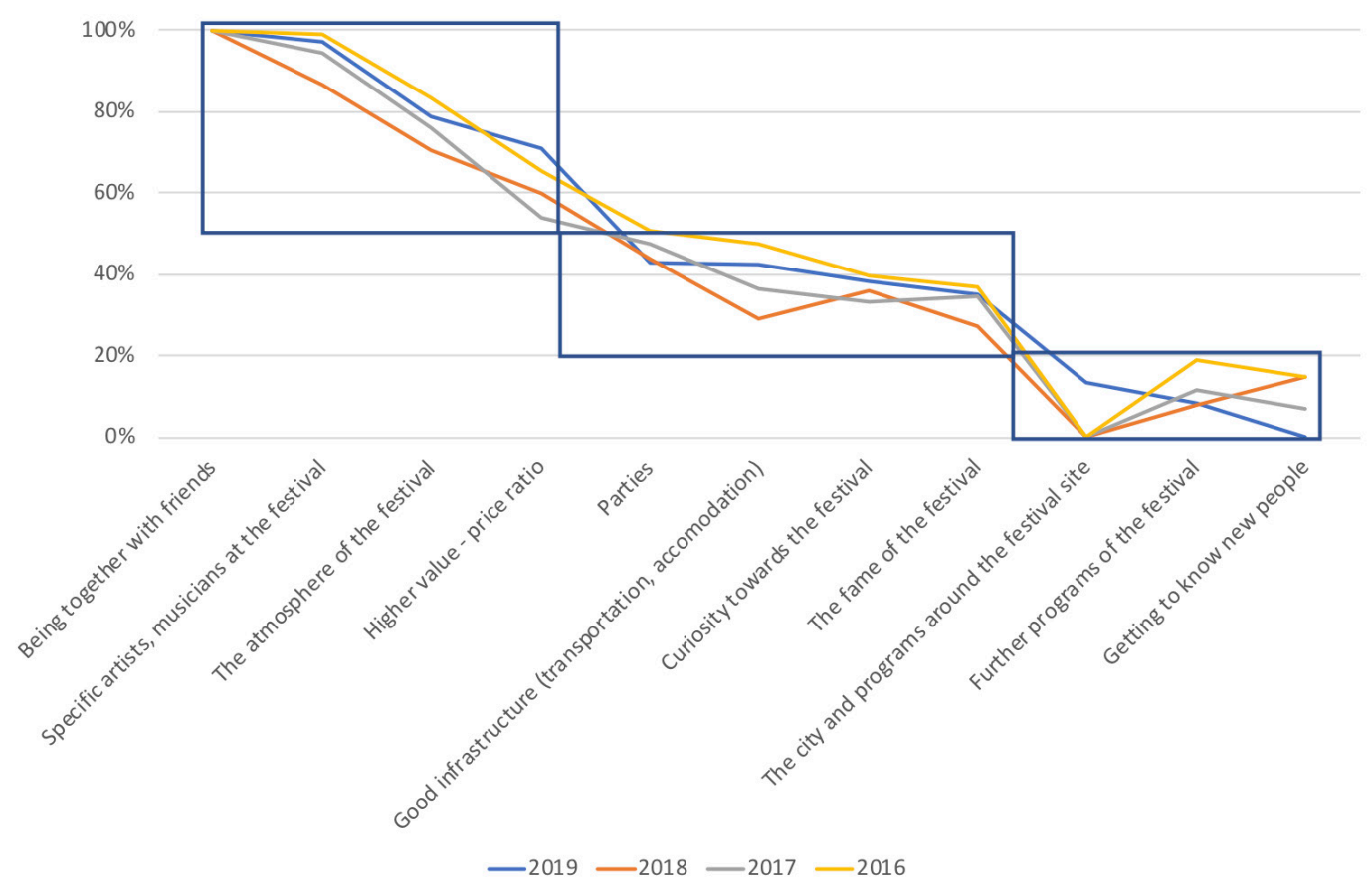

Fig. 4 The motivating factors for choosing a music festival (relative value)

Parties, infrastructure, the visitors' curiosity and fame of the festival were also mentioned several times as important factors. Their relative importance is between 30 to $50 \%$ every year. User generated content in social media (like party pictures, videos, and previously shared experiences) can provide valuable information about the atmosphere (one of the most important factors), the parties, the infrastructure and also can enhance curiosity towards a festival. This can explain the importance and the usage frequency of social media networks, photo and video sharing sites.

In the case of the leading Hungarian music festivals, the city or place where the festival is held is much less important for the visitors in the samples. This can also mean that a festival can help fewer stakeholders in the city and visitors are not intending to spend more time in the surrounding of the festival site. Getting to know new people and the further programmes of the festival are also less important when visitors make a decision about a festival, although these can all enhance the experience when a visitor arrives there. Enhancing visitors' experience can also help prompt them to share posts on social media, thereby creating the feedback loop (Semrad and Rivera, 2018). These factors are not so important in the tourist decision-making process, but for the sake of achieving a more efficient feedback loop, these festivals should also aim to provide a great visitor experience.

Based on the ascribed importance of sixteen information sources for both tourism in general and festival tourism in particular, three segments of the visitors were formed in the sample of 2019 by using hierarchical cluster analysis (see detailed methodology in Section 3). Using the scree diagram, agglomeration schedule and ANOVA tables together with a comparison of the ascribed levels of importance in the case of the sixteen information sources, it was decided to use three clusters, although two and four clusters were also created with the same method. Based on the most frequently used information sources, three different types of the sources were identified, and these three source types are closely connected to the three clusters of the visitors (one group of information sources is important only for one cluster, one group for two clusters and the third group is essential for each cluster). Fig. 5 shows the frequency of usage in the case of the three identified clusters. According to the ANOVA table significant $(p<0.03$ for each case) differences can be seen for all of the cases. Altogether ten different online sources were available to mark in the survey. The number of sources that were marked was counted also. The differences among the three clusters' distributions was evaluated with crosstables and Chi-square test $(p<0.001)$. Fig. 6 also shows the relative importance of the sources to each other in the same group. Based on the results of Figs. 5 and 6 the three identified group were shortly explained and named:

1. Browsers: Those who belong here $(45 \%$ of the sample) mainly gather information from the official websites and search for the information in search engines. These are not just the two mostly used but the two most important sources too for the most of them. Also, those who use rather offline than online 


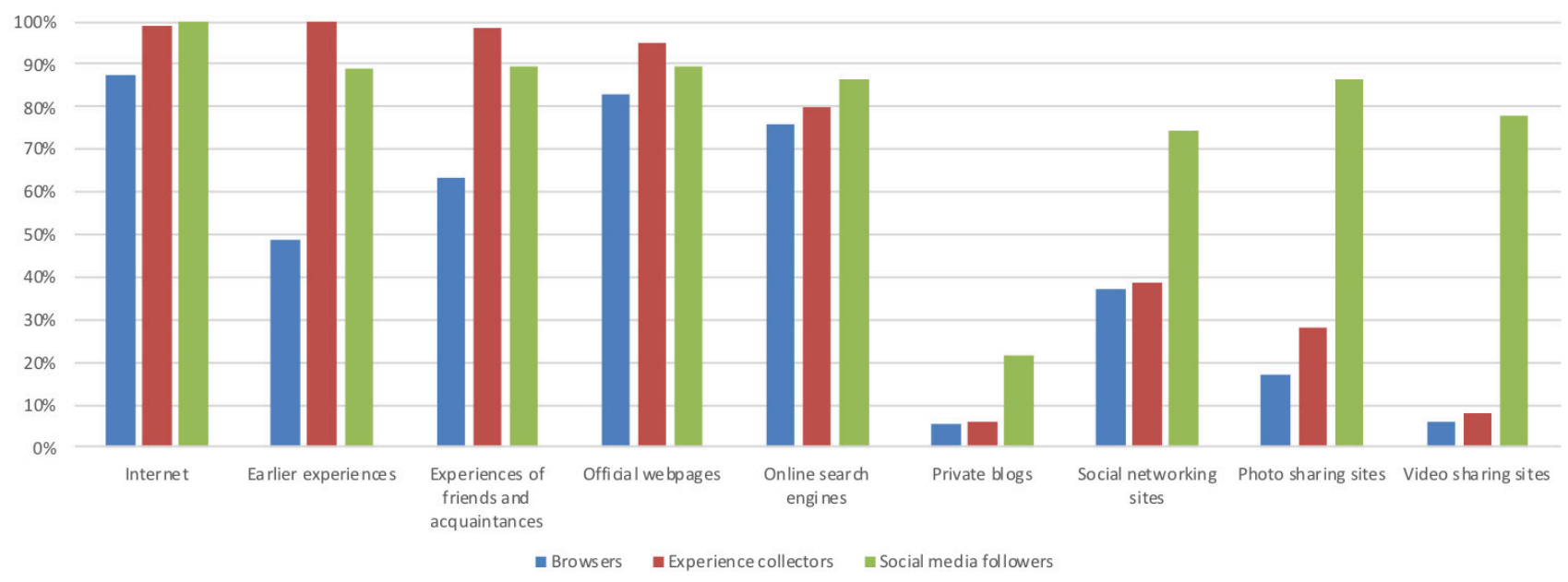

Fig. 5 The frequency of source usage in the case of different groups

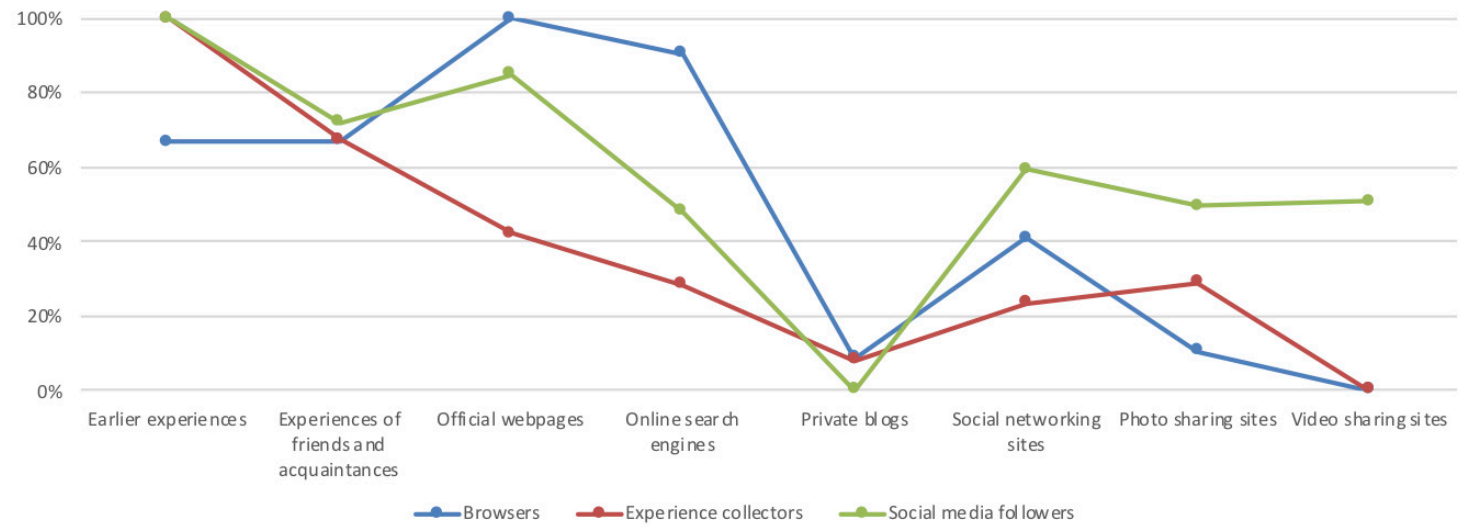

Fig. 6 The relative importance of source usage in the case of different groups

information sources belong to this category. For them, earlier experiences and the experiences of others and also social media sites are not used or even if the use them these are much less relevant in the decision phase and information gathering. Based on these we can call them the users of Web 1.0. Compared to the facts written in the literature review the size of this group is quite significant. Further research should pay attention to changes in the size of this group and to whether its members get transformed into members of the other two groups. The average number of online sources marked by the group members is 2.44 (out of the ten available online sources).

2. Experience collectors: Those who belong here (20\% of the sample) use not just the official websites and search engines, but also focus on the experiences of others and their earlier experiences. In fact, for them the relative importance of the official webpages, the search engine and the social media is not so high compared to the experiences that they can collect from others and their memory. The average number of online sources used by the members of this group (2.57) is not much higher than for the Browsers. This also shows that they are not using much more sources but rather focus on mainly experience and word-of-mouth. Collecting the experiences of friends and making a decision based on these can be an important factor as we could see (Fig. 4) that the prospect of being together with friends plays an important role when deciding which festival to visit. Members of this group also use less sources from offline marketing communication.

3. Social media followers: Those who belong here ( $35 \%$ of the sample) use social media sites also, not just the websites, search engines and experiences that they can collect. In terms of ascribed relative importance, we still can see that social media sites are not so important overall, but nevertheless when compared to the perceptions of the other two groups, these have much higher values. Still, experiences and 
official websites have quite significant importance. It looks as though the members of this group try to collect information from several places and they also try to balance the importance of these sources too. The average number of online sources used by them is significantly larger than for the other two groups (4.49) and they also sometimes use offline marketing communication sources, too. As has been shown earlier, social networking sites and video sharing sites (used mainly by members of this group) experienced a decrease in use over the four-year period examined. This might also be explained bythe change in the size of this group, so further research should pay attention to this group's size as well.

\section{Conclusions and managerial implications}

Based on the results detailed in the previous section, some important managerial implications can be formed for the organizers of the festivals and also the stakeholders in connection to the festivals and festival organizers. Although numbers of studies deal with the importance of social media in tourism and information gathering, there is a limited number of articles paying attention to events and festivals and focusing on the needs of Generation $\mathrm{Z}$.

As the results of the primary quantitative research, social network sites, photo and video sharing sites can play a vital role in the case of music festivals for the members of Generation Z. However, the usage of social network sites and video sharing sites has been decreasing during the last few years, according to the samples of Generation Z. It is not clear what will happen in the future years because there is a significant number of people (the group of Social media followers) who use these sites intensively and try to give importance to them during their information-gathering process. Furthermore, longitudinal research showed that generally the usage of social network sites and video sharing sites are decreasing. It is an important task for the festival organizers to maintain or increase the size of this group. Creating virtual community websites could be a powerful platform for them because they can collect a lot of several types of user-generated content, which could be accessed faster, and more easily from a single platform. Virtual communities - which are still not available in the case of music festivals - can represent blue ocean strategies too for the organizers. Communities also help the organizers to gain more viral (earned) and user generated content (Csordás and Nyirő, 2013), which is usually considered more reliable by the users.
It is important that previous memories of the visitors and friends can have a significant impact on the decision-making process. These shared memories can be gathered from social media platforms and can influence some of the important motivation factors for decisions relating to music festivals (atmosphere, fame, infrastructure, parties, curiosity). This part of information gathering is the most important for Experience collectors, but as we can see, they use social media less frequently, and these sources are less critical for them. Here the organizers have two possible strategies: on the one hand, they have to understand why these people do not use social media platforms when these are full of experiences of other people. On the other hand, these people should be notified about the high quality and quantity of user-generated content that can help them. The group of Browsers should be the hardest to convince to use social media. They are rather focusing on the classical, Web 1.0 modes of information gathering. Also, members of all three groups should be convinced to share their experiences. That is how they can help others. This can be easier in the case of Social media followers, as Kang and Schuett (2013) found a moderately positive relationship between those who have been helped by others through social media to plan their travel and those who are more open to sharing their experiences after the trip and thus helping others. Not only should motivating users to share information be an important consideration when festival organizers plan their communication strategies, but they should also focus on how to lead users from their websites to social media sites and applications during the information gathering process. As can be seen, official websites are important for members of all the three segments, so these websites should be at the centre of all communications, but they should also be redesigned with a view to suggesting that visitors use social media more frequently during the information gathering phase and the post-trip phase too.

\section{Limitations and future plans}

There are also some limitations to this study. Firstly, it is limited to the Hungarian attendants of music festivals from Hungary, so the findings cannot simply be generalised to other festivals like gastronomy, folklore or classical music festivals. Further studies should be conducted on different types of festivals so that the results could be compared to each other.

Secondly, this study focuses on generation Z (the target market of Hungarian music festivals). However, for a detailed understanding of the decision-making process of 
the visitors, more attention should be paid to other generations and the results obtained thereby should also be compared to those presented here. Also, the preferences and motivations of the three groups should be examined in a more detailed way in order to permitthe creation of more efficient marketing communications. As was mentioned in the results section, longitudinal research should be also conducted to permit a better understanding of the change in the size of the three identified groups.

Finally, this study mainly focuses on the pre-trip phase, but as could be seen from the literature review, social media applications are also important during the trip and in the post-trip phase too. As it is part of tourism, it can be interpreted as a service, so the service marketing models and tourism marketing models should be investigated,

\section{References}

Ásványi K., Mitev, A., Jászberényi, M., Mert, M. (2019) "Családok fesztiválélménye - két családbarát fesztivál elemzése" (Festival experience of families - analysis of two family-friendly festivals), Turizmus Bulletin, 19(3), pp. 30-37. (in Hungarian)

Bóta, L. (2009) "Web page navigation analyses for marketing management decision-making", Periodica Polytechnica Social and Management Sciences, 17(2), pp. 89-95. https://doi.org/10.3311/pp.so.2009-2.05

Choe, Y., Kim, J., Fesenmaier, D. R. (2017) "Use of social media across the trip experience: An application of latent transition analysis", Journal of Travel and Tourism Marketing, 34(4), pp. 431-443. https://doi.org/10.1080/10548408.2016.1182459

Choi, S., Lehto, X. Y., Morrison, A. M., Jang, S. (2012) "Structure of Travel Planning Processes and Information Use Patterns", Journal of Travel Research, 51(1), pp. 26-40. https://doi.org/10.1177/0047287510394191

Confente, I., Vigolo, V. (2018) "Online travel behaviour across cohorts: The impact of social influences and attitude on hotel booking intention", International Journal of Tourism Research, 20(5), pp. $660-670$. https://doi.org/10.1002/jtr.2214

Csordás, T., Nyirő, N. (2013) "A marketingkommunikációs eszközök klasszifikációjának kérdése" (Questions about the classification of the marketingcommunication tools), In: Horváth, D., Bauer, A. (eds.) Marketingkommunikáció, Akadémiai Kiadó, Budapest, Hungary, pp. 382-393. (in Hungarian) https://doi.org/10.1556/9789630597227

Deli-Gray, Zs. (2010) "A Sziget" (The Sziget), In: Deli-Gray, Zs., Árva, L. (eds.) Turizmusmarketing esettanulmányok, Akadémiai Kiadó, Budapest, Hungary, pp. 129-137. (in Hungarian)

Drengner, J., Jahn, S., Gaus, H. (2012) "Creating Loyalty in Collective Hedonic Services: The Role of Satisfaction and Psychological Sense of Community", Schmalenbach Business Review, 64(1), pp. 59-76. https://doi.org/10.1007/BF03396838

Evans, D. (2008) "Social Media Marketing: An Hour a Day", Wiley, New York, NY, USA. too. Also, other external factors like health issues, terrorism, global political news, changes and threats can influence the decision-making process and change tourists' approach towards information gathering. These, too, should be investigated in further studies.

\section{Acknowledgement}

The paper was supported by the "ÚNKP-19-3 New National Excellence Programme of the Ministry for Innovation and Technology".
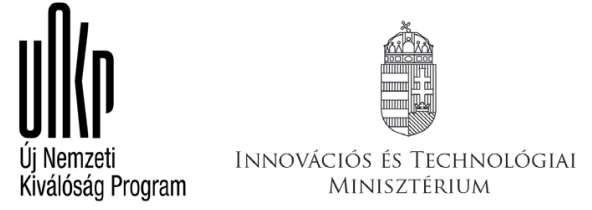

Fazekas, I., Harsányi, D. (2011) "Marketingkommunikáció érthetően" (Marketingcommunication in an understandable way), Szókratész Kiadó, Budapest, Hungary (in Hungarian)

Getz, D. (2008) "Event tourism: Definition, evolution, and research", Tourism Management, 29(3), pp. 403-428. https://doi.org/10.1016/j.tourman.2007.07.017

Hack-Handa, J., Pintér, R. (2015) "Generációs különbségek a magyar médiafogyasztásban" (Generational differences in Hungarian media consumption), Információs társadalom, 15(2), pp. 7-17. (in Hungarian) [online] Available at: http:// epa.oszk.hu/01900/01963/00048/pdf/EPA01963_informacios tarsadalom_2015_2_007-017.pdf [Accessed: 10 March 2020]

Hair, J. F., Black, W. C., Babin, B. J., Anderson, R. E. (2014) "Multivariate data analysis", Pearson, Essex, UK.

Hardey, M. (2011) "Generation C: Content, Creation, Connections and Choice", International Journal of Market Research, 53(6), pp. $749-770$. https://doi.org/10.2501/IJMR-53-6-749-770

Harsányi, D. (2013) "Események és élmények- (Events and experiences), In: Horváth, D., Bauer, A. (eds.) Marketingkommunikáció, Akadémiai Kiadó, Budapest, Hungary. (in Hungarian) https://doi.org/10.1556/9789630597227

Hinek, M., Kulcsár, N. (2019) "A fesztiválélmény megjelenése a közösségi médiában: a Sziget Fesztivál példája" (The appearance of festival experience in social media: the example of Sziget Festival), Turizmus Bulletin, 19(3), pp. 4-12. (in Hungarian)

Huang, C. D., Goo, J., Nam, K., Yoo, C. W. (2017) "Smart tourism technologies in travel planning: The role of exploration and exploitation", Information and Management, 54(6), pp. 757-770. https://doi.org/10.1016/j.im.2016.11.010

Hunyadi, Zs., Inkei, P., Szabó, J. Z. (2006) "Fesztivál-Világ" (Festival World), Kelet-Közép-Európai Kulturális Obszervatórium Alapítvány, Budapest, Hungary. (in Hungarian)

Husz, A. (2012) "Turizmus, fesztiválok és helyi vonzerő" (Tourism, festivals and local attractions), In: Aubert, A., Gyuricza, L., Huszti, Zs. (eds.) A kultúra turizmusa a turizmus kultúrája, Publikon Kiadó, Pécs, Hungary. (in Hungarian) 
Jászberényi, M., Zátori, A., Ásványi, K. (2016) "Fesztiválturizmus" (Festival tourism), Akadémiai Kiadó, Budapest, Hungary. (in Hungarian)

https://doi.org/10.1556/9789634540083

Kang, M., Schuett, M. A. (2013) "Determinants of Sharing Travel Experiences in Social Media", Journal of Travel and Tourism Marketing, 30(1-2), pp. 93-107. https://doi.org/10.1080/10548408.2013.751237

Kang, S., Jodice, L. W., Norman, W. C. (2019) "How do tourists search for tourism information via smartphone before and during their trip?", Tourism Recreation Research. https://doi.org/10.1080/02508281.2019.1627076

Kántor, Sz. (2019) "Kultúra fogyasztási szokások felsőoktatási intézményben tanulók körében" (Habits of cultural consumpsion in the case of university students), In: Csapó, J., Gonda, T., Raffay, Z. (eds.) Turizmus, fogyasztás, generációk: II. Nemzetközi Turizmus Konferencia: Tanulmánykötet, Pécs, Pécsi Tudományegyetem Közgazdaságtudományi Kar, Hungary, pp. 35-44. (in Hungarian)

Kazár, K. (2016) "A márkaközösségek pszichológiai érzetének vizsgálata egy zenei fesztivál esetén" (Research about the psychological sense of brand community in the case of a music festival), In: Fehér, A., Kiss, V. Á., Soós, M., Szakály, Z. (eds.) Hitelesség és Értékorientáció a Marketingben, Debreceni Egyetem Gazdaságtudományi Kar, Debrecen, Hungary, pp. 375-386. (in Hungarian)

Kim, H., Xiang, Z., Fesenmaier, D. R. (2015) "Use of The Internet for Trip Planning: A Generational Analysis", Journal of Travel and Tourism Marketing, 32(3), pp. 276-289. https://doi.org/10.1080/10548408.2014.896765

Kovács, G. (2009a) "A Sziget Fesztivál és a Balaton Sound látogatói" (The visitors of Sziget Festival and Balaton Sound), Turizmus Bulletin, 13(3), pp. 71-72. (in Hungarian)

Kovács, G. (2009b) "A Sziget Fesztivál turisztikai vonatkozásai" (The touristical connections of Sziget Festival), Turizmus Bulletin, 13(1), pp. 28-33. (in Hungarian)

Lai, C.-H., Katz, J. E. (2012) "Are we evolved to live with mobiles? An evolutionary view of mobile communication", Periodica Polytechnica Social and Management Sciences, 20(1), pp. 45-54. https://doi.org/10.3311/pp.so.2012-1.05

Lecinski, J. (2011) "Winning the Zero Moment of Truth", [online] Available at: https://www.thinkwithgoogle.com/future-ofmarketing/emerging-technology/2011-winning-zmot-ebook/ [Accessed: 10 March 2020]

Lévai, R. (2018) "A Facebook és a magyarok [elemzés 2018 augusztus]" (Facebook and the Hungarians [An analysis in August 2018]), [online] Available at: https://kozossegikalandozasok. hu/2018/08/07/a-facebook-es-a-magyarok-elemzes-2018augusztus/ [Accessed: 25 May 2020]

Magyar Turisztikai Ügynökség (2017) "Riport a rekordévröl: Turizmus Magyarországon 2016" (Report about the year of record: Hungary 2016), Magyar Turisztikai Ügynökség, Budapest, Hungary. (in Hungarian) [online] Available at: https://mtu.gov. hu/documents/prod/mid_HU_Turizmus_mo_2016_spreads.pdf [Accessed: 10 March 2020]

Morgan, M. (2008) "What makes a Good Festival? Understanding the Event Experience", Event Management, 12(2), pp. 81-93. https://doi.org/10.3727/152599509787992562
Munar, A. M., Jacobsen, J. K. S. (2014) "Motivations for sharing tourism experiences through social media", Tourism Management, 43, pp. $46-54$.

https://doi.org/10.1016/j.tourman.2014.01.012

Nagy, Á., Fazekas, A. (2016) "Offline helyett online szabadidő?" (Online free time instead of offline free time?), Médiakutató, 16(2), pp. 41-57. (in Hungarian) [online] Available at: http://mediakutato. hu/cikk/2016_02_nyar/03_offline_helyett_online_szabadido.pdf [Accessed: 20 April 2018]

Navío-Marco, J., Ruiz-Gómez, L. M., Sevilla-Sevilla, C. (2018) "Progress in information technology and tourism management: 30 years on and 20 years after the internet - Revisiting Buhalis \& Law's landmark study about eTourism", Tourism Management, 69, pp. $460-470$. https://doi.org/10.1016/j.tourman.2018.06.002

Nemec Rudež, H., Vodeb, K. (2015) "Students' use of social media during the travel process", Tourism and Hospitality Management, 21(2), pp. 179-190.

https://doi.org/10.20867/thm.21.2.5

O’Sullivan, D., Jackson, M. J. (2002) "Festival Tourism: A Contributor to Sustainable Local Economic Development?", Journal of Sustainable Tourism, 10(4), pp. 325-342. https://doi.org/10.1080/09669580208667171

Pál, E. (2013) "a Z generációról...: irodalmi áttekintés" (About Generation Z: a literature review), Pécsi Tudományegyetem, Pécs, Hungary. (in Hungarian) [online] Available at: http://www. zgeneracio.hu/getDocument/4252 [Accessed: 10 March 2020]

Pomucz, A. B., Csete, M. (2015) "Sustainability Assessment of Hungarian Lakeside Tourism Development", Periodica Polytechnica Social and Management Sciences, 23(2), pp. 121-132. https://doi.org/10.3311/PPso.7506

Prensky, M. (2001) "Digital Natives, Digital Immigrants Part 1", On the Horizon, 9(5), pp. 1-6. https://doi.org/10.1108/10748120110424816

Rátz, T. (2012) "A kultúra élménye, az élmény kultúrálja - A fesztiválok szerepe a kulturális turizmusban" (Experience of culture, culture of experience - The role of festivals in cultural tourism), In: Aubert, A., Gyuricza, L., Huszti, Zs. (eds.) A kultúra turizmusa a turizmus kultúrája, Publikon Kiadó, Pécs, Hungary, pp. 35-44. (in Hungarian)

Sajtos, L., Mitev, A. (2007) "SPSS Kutatási és adatelemzési kézikönyv" (SPSS research and data analysis handbook), Alinea Kiadó, Budapest, Hungary. (in Hungarian)

Sija, M., Schauermann, P. (2009) "A 15-25 éves fiatalok fesztivállátogatási szokásai" (The festival visiting habits of youngsters between 15-25), Turizmus Bulletin, 13(3), pp. 28-30. (in Hungarian)

Süli, D., Martyin-Csamangó, Z. (2017) "A közösségi média szerepe a fesztiválturizmusban - a Szegedi Ifjúsági Napok és a Green Future példáján" (The role of social media in the case of festival tourism - The example of Youth Days in Szeged and Green Future), Turizmus Bulletin, 17(3-4), pp. 24-32. (in Hungarian)

Süli, D., Tóth, B., Nagy, Gy., Martyin-Csamangó, Z. (2019) "Az utazással kapcsolatos attitűdök és vélemények Magyarországról mint turisztikai desztinációról az Y és Z generáció körében" (Travel-related attitudes and opinions on Hungary among the $\mathrm{Y}$ and $\mathrm{Z}$ generations), In: Csapó, J., Gonda, T., Raffay, Z. (eds.) Turizmus, fogyasztás, generációk, Pécsi Tudományegyetem Közgazdaságtudományi Kar, Pécs, Hungary, pp. 20-34. (in Hungarian) 
Székely, L., Szabó, A. (2017) "Magyar ifjúság kutatás 2016: az ifjúságkutatás első eredményei" (Research of Hungarian youth 2016: the first results of the research), Új Nemzedék Központ, Budapest, Hungary. (in Hungarian) [online] Available at: http:// www.ujnemzedek.hu/sites/default/files/magyar_ifjusag_2016_ a4_web.pdf [Accessed: 10 March 2020]

Töröcsik, M. (2011) "Fogyasztói magatartás: Insight, trendek, vásárlók" (Consumer behavior: Insight, trends, customers), Akadémiai Kiadó, Budapest, Hungary. (in Hungarian)

Töröcsik, M., Szücs, K., Kehl, D. (2014) "Generációs gondolkodás A Z és az Y generáció életstílus csoportjai" (Generational way of thinking - The lifestyle of Generation $\mathrm{Z}$ and Y), Marketing \& Menedzsment, 48(2-Special Issue), pp. 3-15. (in Hungarian)

Yoo, K.-H., Gretzel, U. (2009) "Comparison of Deceptive and Truthful Travel Reviews", In: Höpken, W., Gretzel, U., Law, R. (eds.) Information and Communication Technologies in Tourism 2009, Springer, Vienna, Austria.

https://doi.org/10.1007/978-3-211-93971-0 4
Vági, B. (2009) "A hazai aktív kulturális közönség vizsgálata a Reneszánsz Év - 2008 keretében" (Research about the local cultural visitors in the case of the year or renaissance 2008), Turizmus Bulletin, 13(3), pp. 48-57. (in Hungarian)

Xiang, Z., Gretzel, U. (2010) "Role of social media in online travel information search", Tourism Management, 31(2), pp. 179-188. https://doi.org/10.1016/j.tourman.2009.02.016

Xiang, Z., Wang, D., O'Leary, J. T., Fesenmaier, D. R. (2015) "Adapting to the Internet", Journal of Travel Research, 54(4), pp. 511-527. https://doi.org/10.1177/0047287514522883

Wang, D., Xiang, Z., Fesenmaier, D. R. (2016) "Smartphone Use in Everyday Life and Travel", Journal of Travel Research, 55(1), pp. 52-63. https://doi.org/10.1177/0047287514535847

Zavodna, L. S., Zavodny Pospisil, J. (2018) "Social media use among Czech university students during the travel process", Tourism and Hospitality Management, 24(1), pp. 213-227. https://doi.org/10.20867/thm.24.1.7 